Louisiana State University

LSU Digital Commons

Faculty Publications

Department of Biological Sciences

$10-1-2008$

\title{
Phylogeny, taxonomy, and evolution of Neotropical cichlids (Teleostei: Cichlidae: Cichlinae)
}

\author{
Wm Leo Smith \\ Field Museum of Natural History \\ Prosanta Chakrabarty \\ American Museum of Natural History \\ John S. Sparks \\ American Museum of Natural History
}

Follow this and additional works at: https://digitalcommons.Isu.edu/biosci_pubs

\section{Recommended Citation}

Leo Smith, W., Chakrabarty, P., \& Sparks, J. (2008). Phylogeny, taxonomy, and evolution of Neotropical cichlids (Teleostei: Cichlidae: Cichlinae). Cladistics, 24 (5), 625-641. https://doi.org/10.1111/ j.1096-0031.2008.00210.x

This Article is brought to you for free and open access by the Department of Biological Sciences at LSU Digital Commons. It has been accepted for inclusion in Faculty Publications by an authorized administrator of LSU Digital Commons. For more information, please contact ir@lsu.edu. 


\title{
Cladistics
}

\section{Phylogeny, taxonomy, and evolution of Neotropical cichlids (Teleostei: Cichlidae: Cichlinae)}

\author{
Wm. Leo Smith ${ }^{\mathrm{a}, \mathrm{b}, *}$, Prosanta Chakrabarty ${ }^{\mathrm{b}}$ and John S. Sparks ${ }^{\mathrm{b}}$ \\ ${ }^{a}$ Field Museum of Natural History, Division of Fishes, 1400 South Lake Shore Drive, Chicago, IL 60605, USA \\ ${ }^{b}$ American Museum of Natural History, Department of Ichthyology, Central Park West at 79th Street, New York, NY 10024, USA
}

Accepted 19 December 2007

\begin{abstract}
Despite recent progress on the higher-level relationships of Cichlidae and its Indian, Malagasy, and Greater Antillean components, conflict and uncertainty remain within the species-rich African, South American, and Middle American assemblages. Herein, we combine morphological and nucleotide characters from the mitochondrial large ribosomal subunit, cytochrome $c$ oxidase subunit I, NADH dehydrogenase four, and cytochrome $b$ genes and from the nuclear histone H3, recombination activating gene two, Tmo-4C4, Tmo-M27, and ribosomal S7 loci to analyse relationships within the Neotropical cichlid subfamily Cichlinae. The simultaneous analysis of 6309 characters for 90 terminals, including representatives of all major cichlid lineages and all Neotropical genera, resulted in the first well-supported and resolved generic-level phylogeny for Neotropical cichlids. The Neotropical subfamily Cichlinae was recovered as monophyletic and partitioned into seven tribes: Astronotini, Chaetobranchini, Cichlasomatini, Cichlini, Geophagini, Heroini, and Retroculini. Chaetobranchini + Geophagini (including the "crenicichlines") was resolved as the sister group of Heroini + Cichlasomatini (including Acaronia). The monogeneric Astronotini was recovered as the sister group of these four tribes. Finally, a clade composed of Cichlini + Retroculini was resolved as the sister group to all other cichlines. The analysis included the recently described $†$ Proterocara argentina, the oldest known cichlid fossil (Eocene), which was placed in an apical position within Geophagini, further supporting a Gondwanan origin for Cichlidae. These phylogenetic results were used as the basis for generating a monophyletic cichline taxonomy.
\end{abstract}

(c) The Willi Hennig Society 2008.

Cichlids are a species-rich clade of acanthomorph fishes that have captured the attention of ecologists, ethologists, and micro- and macroevolutionary biologists (Keenleyside, 1991; Barlow, 2000; Kornfield and Smith, 2000). They represent the largest clade of freshwater euteleosts (Nelson, 2006) and exhibit a Gondwanan distribution, with representatives found throughout Africa, South and Middle America (including Texas), Madagascar, India, Sri Lanka, Cuba, Hispaniola, Syria, Israel, and Iran (Stiassny, 1991; Chakrabarty, 2004; Sparks and Smith, 2004). Initial morphology-based phylogenetic work suggested that the Neotropical and African lineages were polyphyletic due to the separation of Heterochromis and/or Cichla from

\footnotetext{
*Corresponding author: E-mail address: 1smith@fieldmuseum.org
}

their continental allies (Oliver, 1984; Stiassny, 1987, 1991; Kullander, 1998), but recent family-level work has recovered all continental assemblages, with the exception of the Malagasy lineages, as monophyletic (Farias et al., 1999; Sparks, 2004; Sparks and Smith, 2004). Phylogeny of the Indian and Sri Lankan (Sparks and Smith, 2004; Sparks, 2008), Malagasy (Sparks and Smith, 2004; Stiassny and Sparks, 2006; Sparks, 2008), and Greater Antillean (Chakrabarty, 2006a, 2007) cichlids has been examined in detail, but conflict and uncertainty remain within the species-rich African and Neotropical clades (Kullander, 1998; Farias et al., 2000, 2001; Sparks and Smith, 2004; Fig. 1).

The Neotropical cichlids (Cichlinae sensu Sparks and Smith, 2004) or "cichlines" include the Middle American and Greater Antillean "heroines" (15 genera, approximately 110 species) as well as 41 extant genera 

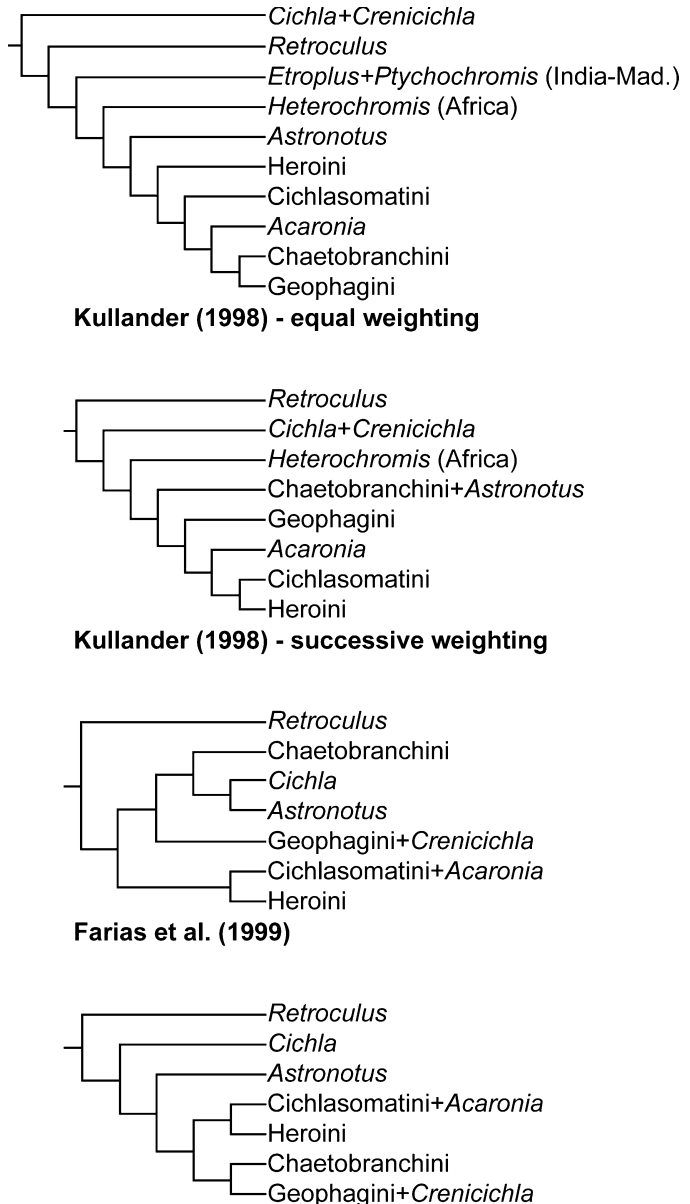

Farias et al. (2000) - total evidence

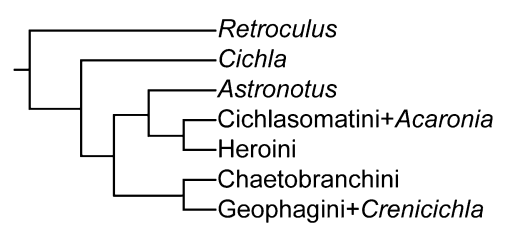

Farias et al. (2001) - total evidence

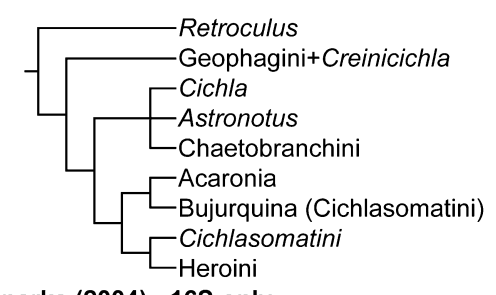

Sparks (2004) - 16S only

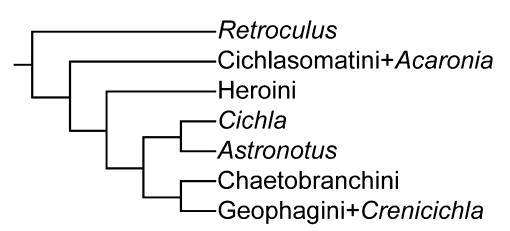

Sparks and Smith (2004) and more than 350 species of South American cichlids (Kullander, 2003; Ŕíčan and Kullander, 2006; Chakrabarty and Sparks, 2007; Schmitter-Soto, 2007). The Neotropics are also home to several important fossils (Casciotta and Arratia, 1993), including the recently described Eocene $\dagger$ Proterocara from Argentina (Malabarba et al., 2006), which represents the oldest known fossil cichlid.

For most of the 20th century, the taxonomy of cichlines followed Regan (1906). Knowledge of cichlid evolution changed significantly after the completion of Cichocki's (1976) dissertation, which provided the first real alternative to Regan's seminal work. Cichocki's (1976) study advanced our understanding of cichlid and cichline relationships, but the evidential significance and resulting hypothesis of relationships were hampered by their reliance on clique analysis (for discussion see Kullander, 1998). Shortly thereafter, a number of researchers built upon Cichocki's (1976) dataset to further our understanding of cichlid intrarelationships (Oliver, 1984; Stiassny, 1987, 1991); however, these studies emphasized the relationships of the family as a whole, providing little additional information on cichline intrarelationships beyond the placement of Cichla. Additionally, a number of influential revisionary and geographical studies were published that provided an incremental refinement of cichlid taxonomy, including the diagnosis and description of several South American genera (Kullander, 1983, 1986, 1988; Kullander and Nijssen, 1989; Kullander and Staeck, 1990). In 1998, our understanding of South American cichlid phylogeny improved dramatically when Kullander published the first generic-level phylogeny of this assemblage. His phylogenetic hypothesis was based on the analysis of a morphological dataset that critically evaluated and incorporated previous phylogenetic and taxonomic characters and included many new characters. Using the results of his successive weighting analysis, Kullander (1998) presented a revised taxonomy of South American cichlids. Subsequently, several molecular studies have provided insights into the relationships within Cichlinae (Farias et al., 1999, 2000, 2001; Sparks, 2004; Sparks and Smith, 2004; Fig. 1). These morphological, molecular, and combined studies have typically recovered monophyletic "chaetobranchines", "cichlasomatines", "geophagines" (often including Crenicichla), and "heroines" [including all Central American (except for a few cichlasomatins and geophagins) and Greater Antillean cichlids], but the interrelationships of these clades (all treated at the tribal level hereafter) and the interrelationships and inclusion/exclusion of the genera

Fig. 1. Prior higher-level hypotheses of Neotropical cichlid intrarelationships based on morphological (Kullander, 1998: fig. 9), molecular (Farias et al., 1999: fig. 2; Sparks, 2004: fig. 3; Sparks and Smith, 2004: fig. 1), or combined (Farias et al., 2000: fig. 3, 2001: fig. 7) evidence. 
Acaronia, Astronotus, Cichla, Crenicichla, and Retroculus remain controversial (Fig. 1).

Despite several recurring phylogenetic patterns among cichlines, there are substantive differences between the various hypotheses at suprageneric levels (Fig. 1). However, this inconsistency represents indecisive rather than contradictory data, as evidenced by the limited branch lengths and support measures recovered for the majority of nodes in these analyses. These differences not only affect our phylogenetic understanding of the extant diversity, but the disagreement between morphological, molecular, and combined studies has ramifications for the placement of $\dagger$ Proterocara. Given that $†$ Proterocara is the oldest known cichlid fossil, its phylogenetic placement is crucial for understanding the evolution and timing the diversification of both Cichlinae and Cichlidae.

\section{Materials and methods}

\section{Taxon sampling}

To provide a robust test of cichline monophyly, two non-cichlid families (Percidae and Embiotocidae), both etropline genera, all five ptychochromine genera, and 17 pseudocrenilabrine genera (including Heterochromis) were included as outgroups. The topology was rooted with a percid (Perca). The 64 cichline terminals analysed herein included representatives of all Central American, South American, and Greater Antillean cichlid genera, eight additional Neotropical species that have been occasionally or consistently separated from their congeners in phylogenetic analyses ["Aequidens" diadema, "A." hoehnei, "A." pulcher, "A." rivulatus, "Cichlasoma" festae, Geophagus brasiliensis, G. steindachneri, and Nannacara (Ivanacara) adoketa], and one Argentine fossil (†Proterocara). Due to slight differences in the taxonomic sampling used in this and prior studies (Kullander, 1998; Farias et al., 2000, 2001), we have chosen, when necessary, to combine data from different congeneric species into single generic terminals (Table 1). The use of supraspecific taxa as terminals follows López-Fernández et al. (2005b) and was done with the goals of including data from all prior explicit higher-level cichline phylogenies (i.e. to test previous hypotheses) and increasing resolution at the generic level. To avoid confusion, we use the ending -ine(s) for subfamilies (e.g. "cichlines" for Cichlinae) and the ending -in(s) for tribes (e.g. "cichlins" for Cichlini).

\section{Molecular sequence data}

A total of 6218 aligned nucleotides [based on the implied alignment (Wheeler, 2003a)] from four mitochondrial [large ribosomal subunit (16S), cytochrome $c$ oxidase subunit I (COI), NADH dehydrogenase four (ND4), and cytochrome $b$ (Cyt-b)] and five nuclear [histone $\mathrm{H} 3(\mathrm{H} 3)$, recombination activating gene two (RAG2), intron one of the S7 ribosomal protein (S7), Tmo-4C4 (4C4), and Tmo-M27 (M27)] gene regions were analysed simultaneously with the morphological data coded in or from Kullander $(1990,1998)$ and Malabarba et al. (2006). The terminals analysed in the present study and GenBank accession numbers corresponding to the gene fragments sequenced are listed in Table 1. All previously published DNA sequence data analysed in this study were taken from the following studies: Zardoya et al. (1996), Lydeard and Roe (1997), Roe et al. (1997), Streelman and Karl (1997), Martin and Bermingham (1998), Mayer et al. (1998), Song et al. (1998), Bernardi and Bucciarelli (1999), Kumazawa et al. (1999), Seegers et al. (1999), Farias et al. (1999, 2000, 2001), Salzburger et al. (2002a,b), Schliewen and Klee (2004), Smith and Wheeler (2004), Sparks (2004), Sparks and Smith (2004), López-Fernández et al. (2005a,b), Westneat and Alfaro (2005), Chakrabarty (2006a,b), Hulsey et al. (2006), Ŕíčan and Kullander (2006), Schelly et al. (2006), Concheiro-Perez et al. (2007), Higham et al. (2007), and Musilová et al. (2008). Note that the Cyt- $b$ sequence of Paratilapia sp. from Farias et al. (2001) was excluded because it appears to be a misidentified etropline cichlid (unpublished data).

\section{Acquisition of nucleotide sequences}

Fish tissues were preserved in $70-95 \%$ ethanol prior to extraction of DNA. Nuclear and mitochondrial DNA was extracted from muscle or fin clips using a DNeasy Tissue Extraction Kit (Qiagen, Valencia, CA, USA). PCR was used to amplify four gene fragments. Double-stranded amplifications were performed in a $25-\mu \mathrm{L}$ volume containing one Ready-To-Go PCR bead (GE Healthcare, Piscataway, NJ, USA), $1.25 \mu \mathrm{L}$ of each primer $(10 \mathrm{pmol})$, and $2-5 \mu \mathrm{L}$ of undiluted DNA extract. Primers and PCR conditions for novel sequences from the $16 \mathrm{~S}, \mathrm{COI}, \mathrm{H} 3$, and $4 \mathrm{C} 4$ genes follow Smith and Wheeler (2004) and Sparks et al. (2005).

The double-stranded amplification products were desalted and concentrated using AMPure (Agencourt Biosciences, Beverly, MA, USA). Both strands of the purified PCR fragments were used as templates and amplified for sequencing using the original amplification primers and a Prism Dye Terminator Reaction Kit Version 1.1 (Applied Biosystems, Foster City, CA, USA) with minor modifications to the manufacturer's protocols. The sequencing reactions were cleaned and desalted using cleanSEQ (Agencourt Biosciences). The nucleotides were sequenced on a 3730XL automated DNA sequencer (Applied Biosystems). Contigs were built in 


\begin{tabular}{|c|c|c|c|c|c|c|c|c|}
\hline & 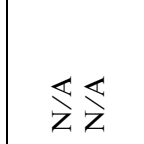 & 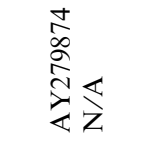 & 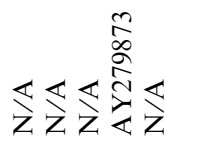 & 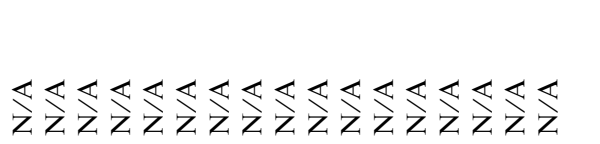 & 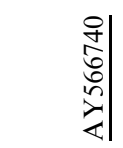 & $\begin{array}{l}\ll \\
z z\end{array}$ & $\ll \ll$ & \\
\hline$\hat{n}$ & $\overleftrightarrow{z} \ll$ & 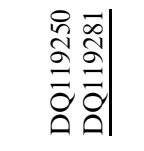 & 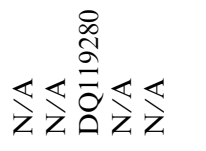 & 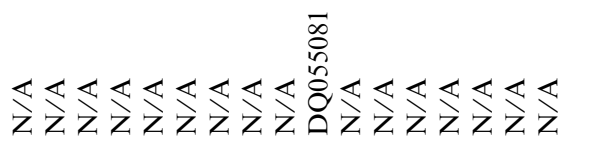 & 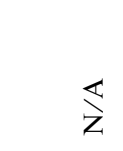 & $\begin{array}{l}\ll \\
z z\end{array}$ & 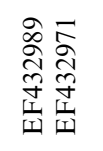 & 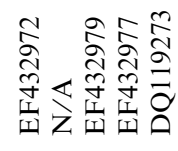 \\
\hline$\widehat{\grave{\Sigma}}$ & 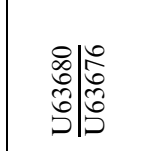 & 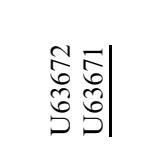 & 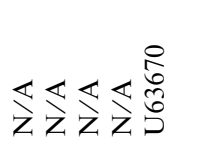 & 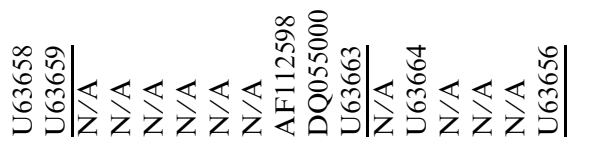 & 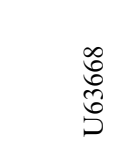 & 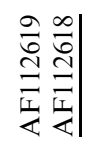 & 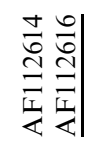 & 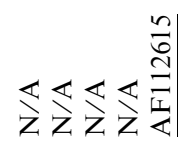 \\
\hline$\cong$ & 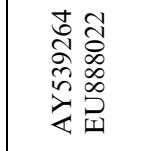 & \begin{tabular}{l}
$\infty$ \\
$\infty$ \\
0 \\
0 \\
0 \\
0 \\
0 \\
\hdashline \\
$<$ \\
$<$
\end{tabular} & 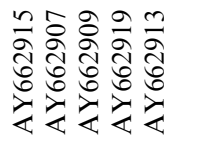 & 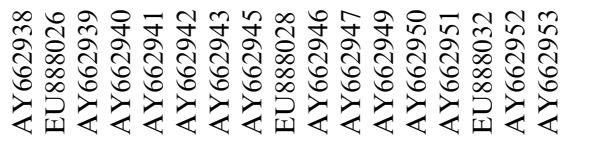 & 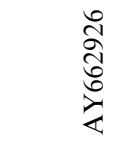 & 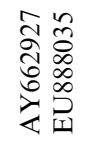 & 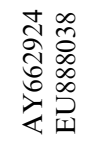 & 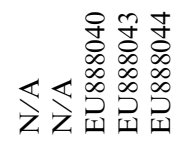 \\
\hline ச্ & 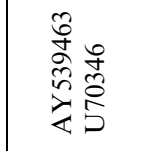 & 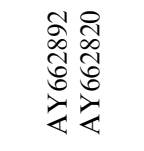 & 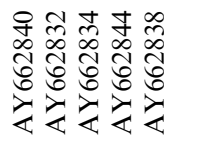 & 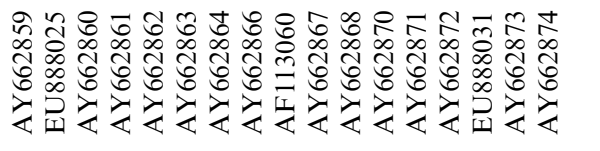 & 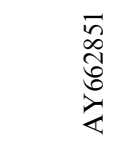 & 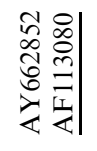 & 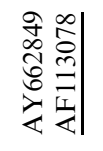 & 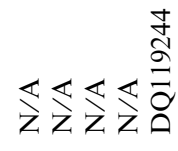 \\
\hline 艺 & 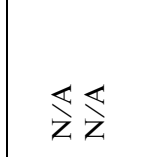 & $\underset{z}{\ll}$ & $\begin{array}{l}\ll \\
\mathrm{z} z\end{array}$ & 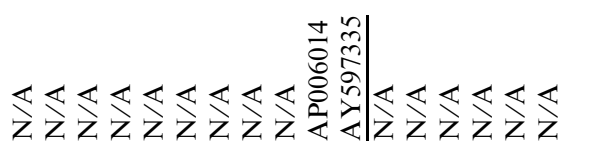 & 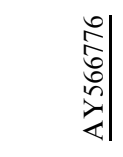 & $\underset{z}{\ll}$ & $\overleftrightarrow{z} \overleftrightarrow{z}$ & \\
\hline 紊 & 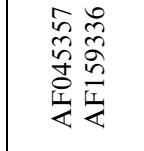 & 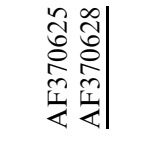 & 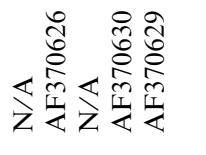 & 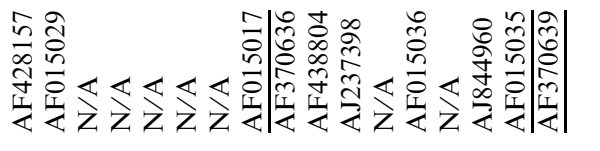 & 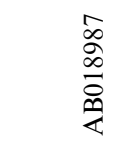 & 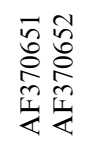 & 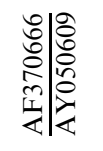 & 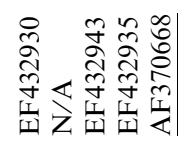 \\
\hline 8 & 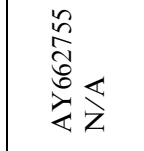 & 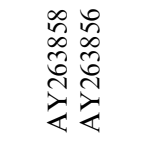 & 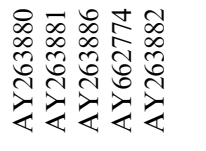 & 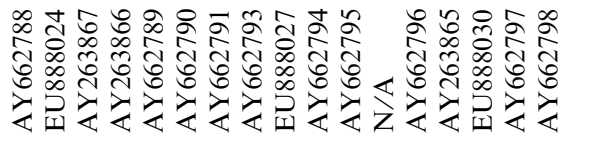 & 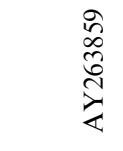 & 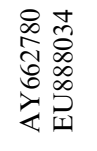 & 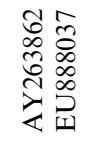 & 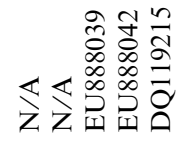 \\
\hline$\underline{0}$ & 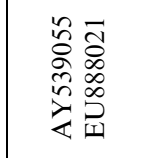 & 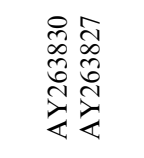 & 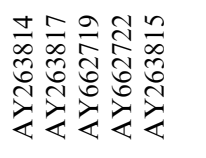 & 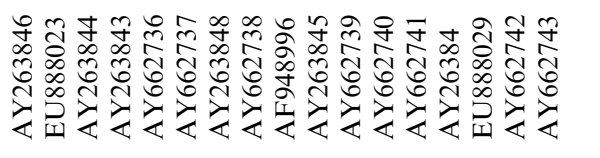 & 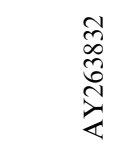 & 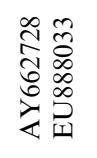 & 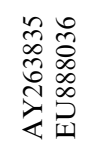 & 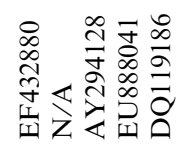 \\
\hline 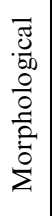 & 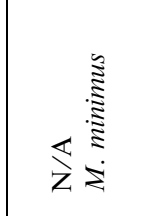 & 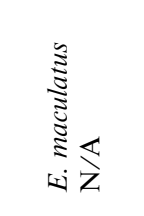 & 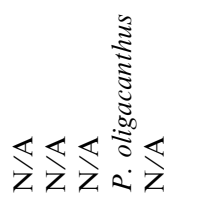 & 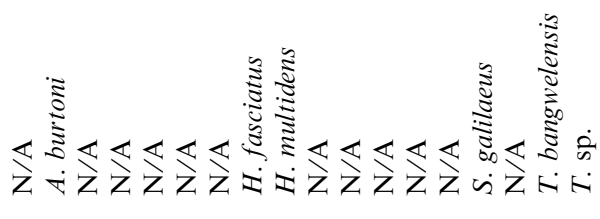 & 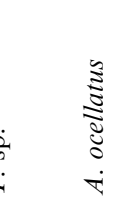 & zu & 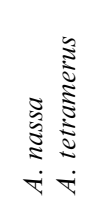 & 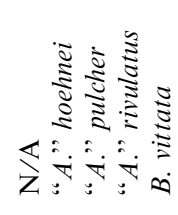 \\
\hline $\begin{array}{l}\frac{\tilde{z}}{\bar{z}} \\
\frac{0}{0} \\
\frac{0}{0}\end{array}$ & 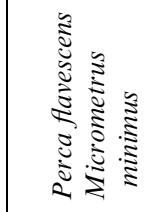 & 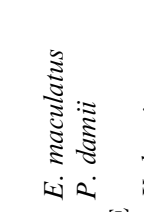 & 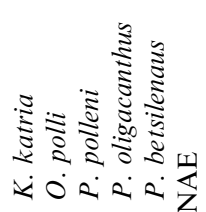 & 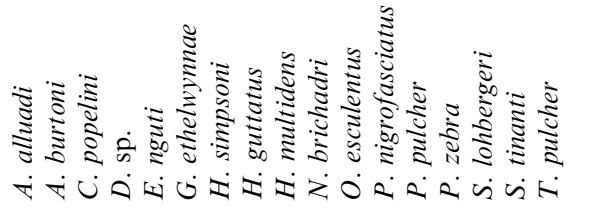 & 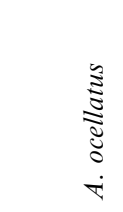 & 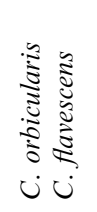 & 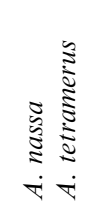 & 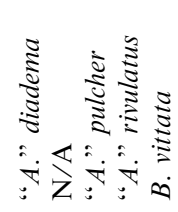 \\
\hline 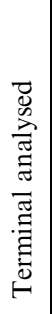 & 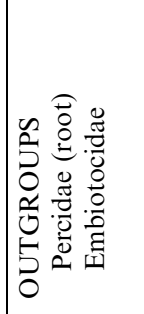 & 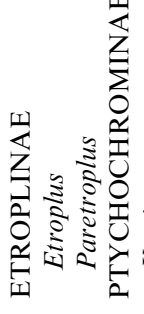 & 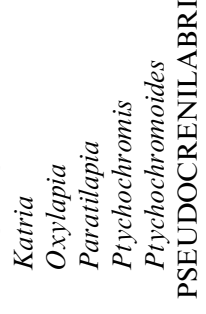 & 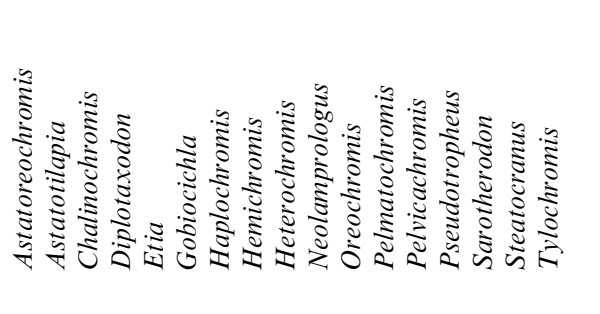 & 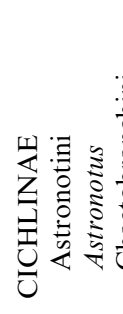 & $\bar{E}$ & 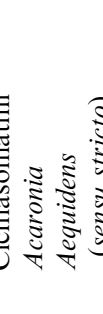 & 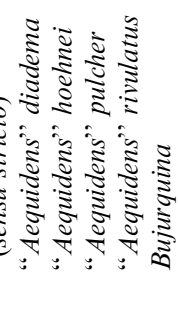 \\
\hline
\end{tabular}




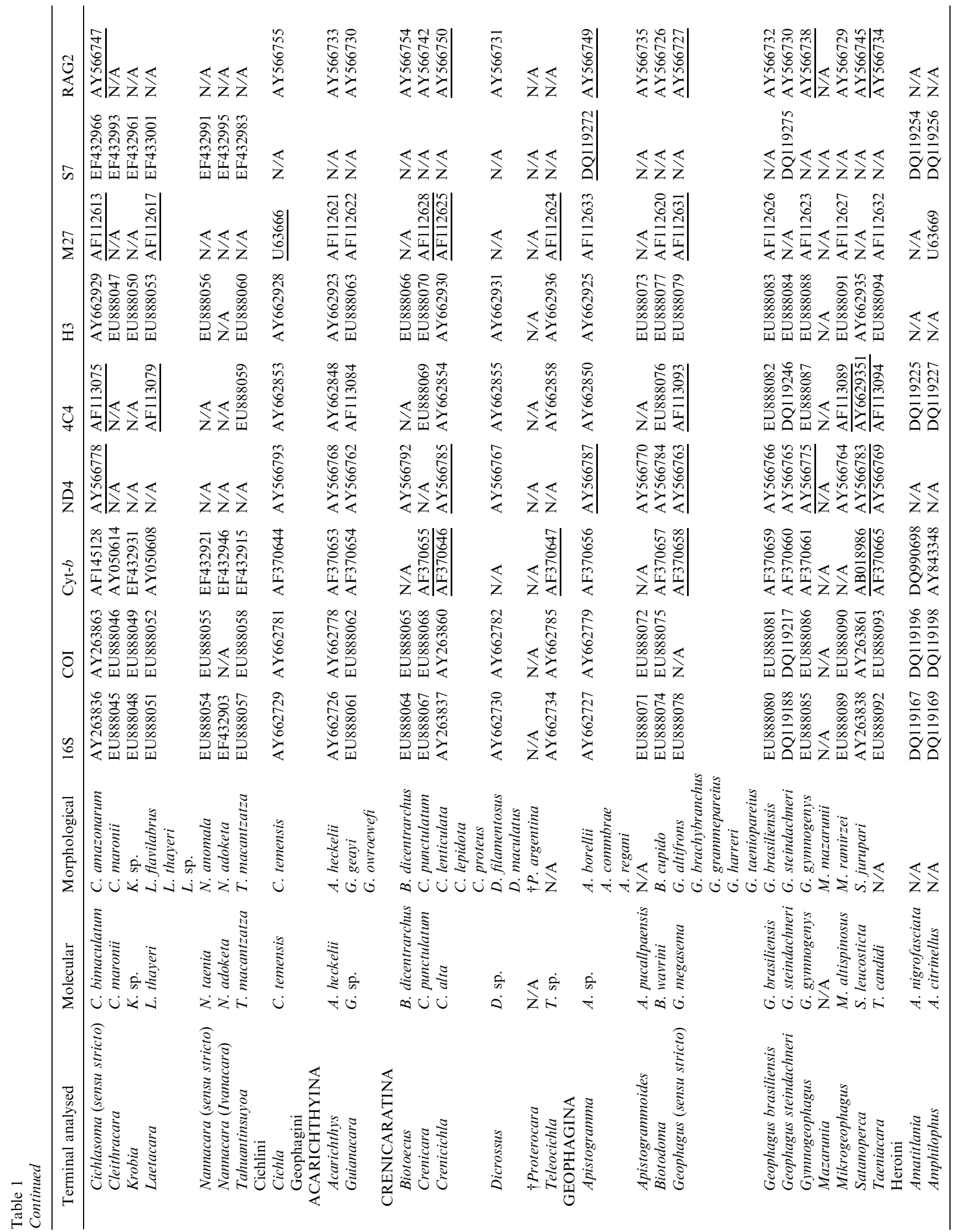




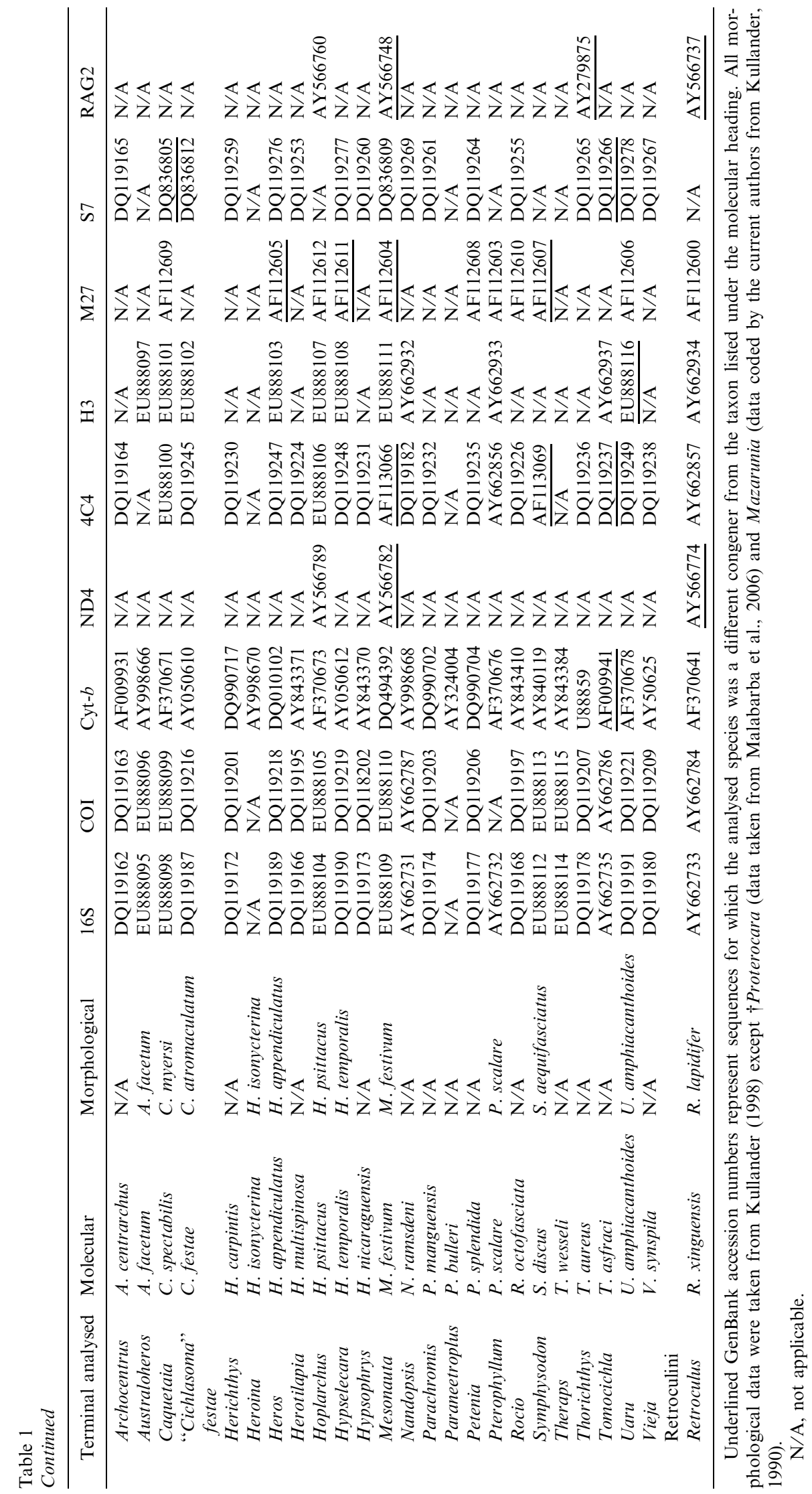


Sequencher (Gene Codes, Ann Arbor, MI, USA) using DNA sequences from the complementary heavy and light strands. Sequences were edited in Sequencher and Bioedit (Hall, 1999). All novel sequences were submitted to GenBank and assigned accession numbers EU888021-EU888116.

\section{Phylogenetic analyses}

For the phylogenetic analysis, the nucleotide characters from the nine gene fragments were combined with the 91 morphological characters identified by Kullander (1998). Two taxa were added to Kullander's (1998) morphological dataset: $\uparrow$ Proterocara, which was coded by Malabarba et al. (2006), and Mazarunia, which was coded herein for all characters that could be scored from its original description (Kullander, 1990). The characters and state (in parentheses) that we were able to code for Mazarunia are as follows: 5(0), 7(1), 12(0), 13(1), 15(2), 39(1), 40(0), 41(2), 42(0), 45-46(0), 62(1), 65(0), 66-67(1), 78(3), 79(0), 81-84(0), 85-86(1), 87-91(0). These morphological and molecular data were simultaneously analysed under the optimality criterion of parsimony with equal weights (i.e. morphological transformations, insertions, deletions, transitions, and transversions all given a weight of 1). The parsimony analysis was conducted using direct optimization (Wheeler, 1996) and iterative pass (Wheeler, 2003b) as implemented in the program POY (Wheeler et al., 2003, 2006). Unlike traditional multiple sequence alignment, which is divorced from the search for optimal tree topologies, direct optimization combines alignment and tree-search into a single procedure to produce globally optimal trees.

The analysis began by generating 250 random addition sequences (RAS), followed by tree fusing (Goloboff, 1999), SPR, and TBR branch swapping. The best trees resulting from these analyses were submitted to 100 TBR-ratchet replicates (Nixon, 1999), tree fusing (Goloboff, 1999), and TBR branch swapping. Following the methods in previous studies (Smith and Wheeler, 2006; Smith and Craig, 2007), all equally optimal trees resulting from this analysis were submitted to POY for more exhaustive tree searching using the commands iterative pass (Wheeler, 2003b) and exact (Wheeler et al., 2006). This second step of the analysis consisted of 100 rounds of TBR ratcheting followed by tree fusing and TBR branch swapping.

The length of the resulting implied alignment (Wheeler, 2003a) was verified in PAUP* (Swofford, 2002). To estimate the "robustness" of the clades recovered in the phylogenetic hypotheses, jackknife percentages (200 replications, five RAS per replicate, using the "emulate jac" option) and Bremer supports (Bremer, 1994; Sorenson, 1999) were calculated in PAUP* based on the resulting implied alignment with $\uparrow$ Proterocara and
Mazarunia removed. $\uparrow$ Proterocara and Mazarunia were removed for the support calculations because they were coded for only 17 and 28 of the 6309 characters, respectively; the addition of taxa with extensive missing data has been shown to improve phylogenetic estimates, but their addition necessarily reduces support measures (Norell and Wheeler, 2003). Branch length calculations represent unambiguous parsimony transformations only, and they were calculated using the program WinClada (Nixon, 2002).

\section{Results}

The combined analysis of the nine gene fragments and the morphological dataset (6309 characters) for 90 terminals resulted in a single most parsimonious tree that had a length of 19921 steps. The optimal phylogenetic hypothesis had a consistency index (CI; Kluge and Farris, 1969) of 0.28 and a retention index (Farris, 1989) of 0.43 when uninformative characters were retained and is presented in Fig. 2. The only lack of resolution in the topology involved rearrangements of the clade composed of Crenicichla, †Proterocara, and Teleocichla due to the lack of morphological data for Teleocichlia and the lack of molecular data for $\dagger$ Proterocara. In the 88-taxon support dataset (excluding $\uparrow$ Proterocara and Mazarunia), a single optimal tree was recovered; this tree was identical to the tree in Fig. 2 if †Proterocara and Mazarunia were removed (see dashed lines in Fig. 2 to note placement of $\uparrow$ Proterocara and Mazarunia). This tree had a length of 19916 steps. Most of the 85 nodes represented in the 88-taxon support analysis were well supported, with 71 nodes $(84 \%)$ having a Bremer support $\geq 5$ and 43 nodes $(51 \%)$ having a Bremer support $\geq 10$. Additionally, 68 nodes $(80 \%)$ were supported by a jackknife value $\geq 70$ and 47 nodes $(55 \%)$ had a jackknife value $\geq 90$.

The family Cichlidae was recovered as monophyletic with strong support (jackknife resampling of $100 \%$ and Bremer support of 41). Furthermore, the limits and interrelationships of all four subfamilies (Etroplinae, Ptychochrominae, Cichlinae, and Pseudocrenilabrinae) were well supported and match Sparks and Smith (2004). The higher-level relationships within Cichlinae differed from all previous explicit hypotheses (compare Figs 1 and 2).

We recovered a monophyletic Cichlasomatini (with the inclusion of Acaronia), Heroini, Chaetobranchini, and Geophagini (with the inclusion of Crenicichla, $\dagger$ Proterocara, and Teleocichla). Geophagini + Chaetobranchini formed a clade that was recovered as the sister-group of Cichlasomatini + Heroini. Astronotus (Astronotini) was resolved as the sister-group to the clade composed of these four cichline tribes 


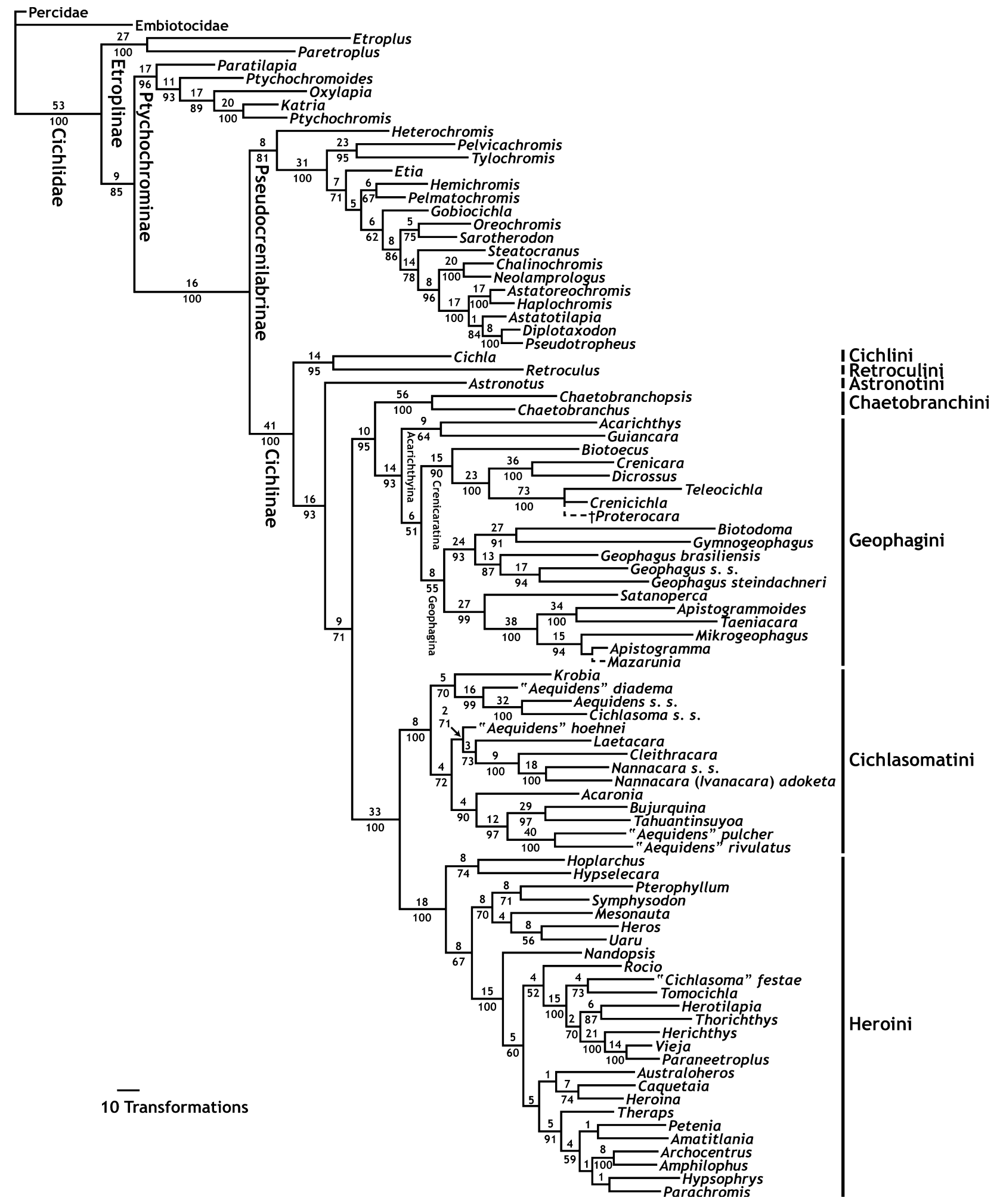

Fig. 2. Single most parsimonious tree with familial, subfamilial, tribal, and subtribal clades identified. Numbers above branches represent Bremer supports and numbers below branches represent jackknife resampling percentages $(>50 \%)$ for each resolved node in the 88 -taxon support analysis with †Proterocara and Mazarunia (dashed branches) removed. The abbreviation s.s. following Aequidens, Cichlasoma, Geophagus, and Nannacara represents sensu stricto. Branch lengths represent unambiguous parsimony transformations. 
(Chaetobranchini, Cichlasomatini, Geophagini, and Heroini). Finally, we recovered a clade composed of Cichla + Retroculus as the sister-group to all other cichlines. Our placement of $†$ Proterocara within Geophagini differs from Malabarba et al. (2006) who recovered this taxon outside of the Chaetobranchi$\mathrm{ni}+$ Cichlasomatini + Geophagini + Heroini clade.

\section{Discussion}

This study was designed to look specifically at the intergeneric relationships of Neotropical cichlids. In particular, we focused on the limits and relationships of, and within, the cichline tribes and the placement of $\dagger$ Proterocara. Furthermore, this study provided an opportunity to refine Kullander's (1998) taxonomy in light of additional taxa and novel morphological and molecular sequence data. Beyond Cichlinae, our results provided an opportunity further to test and re-examine some of the higher-level relationships within Cichlidae. Our results corroborate Sparks and Smith's (2004) phylogeny regarding the limits and relationships of Cichlidae and its four subfamilies. This hypothesis posits that the African Pseudocrenilabrinae and Neotropical Cichlinae are reciprocally monophyletic and sister taxa. The results also support the Malagasy Ptychochrominae as this African-Neotropical clade's sister group and the Malagasy-Indian Etroplinae as the sister-group of all other cichlids.

The current study provides an opportunity to test some of the more contentious problems in cichlid phylogenetics (e.g. placement of Cichla and Heterochromis within the cichlid radiation). Morphological studies (Oliver, 1984; Stiassny, 1991; Kullander, 1998) have excluded Heterochromis from Pseudocrenilabrinae. Furthermore, Oliver (1984) excluded Cichla from the Neotropical assemblage, placing the genus in an unresolved trichotomy with Heterochromis and the combined Neotropical-African lineage (excluding Cichla and Heterochromis). Stiassny (1987) refuted Oliver's placement of Cichla and provided morphological evidence for the placement of Cichla in the Neotropical clade. Molecular studies have corroborated Stiassny's (1987) placement of Cichla within the Neotropical assemblage and have generally recovered Heterochromis within Pseudocrenilabrinae (Farias et al., 1999, 2000; Sparks, 2004; Sparks and Smith, 2004; but see Farias et al., 2001: figs 3-6). As with recent molecular and combined analyses, we recovered the continental lineages, except Madagascar, as monophyletic. Additionally, this study recovered anatomical support for the monophyly of the African cichlids, which has been elusive (Sparks and Smith, 2004). Kullander (1998) suggested that the loss of ceratobranchial four toothplates and the presence of two posterodorsal palatine wing-lateral ethmoid ligaments would support a monophyletic Pseudocrenilabrinae, a supposition corroborated by the present analysis.

\section{Cichlinae}

Casciotta and Arratia (1993) were the first researchers explicitly to examine relationships within Neotropical cichlids in a cladistic framework; their work included approximately half of the South American genera and focused on the placement of several Tertiary fossils. Kullander (1998) built upon the work of Cichocki (1976), Casciotta and Arratia (1993), and Stiassny (1991). Kullander (1998) noted problems with the prior studies [e.g. the clique analysis of Cichocki (1976), the overemphasis of piscivory-related characters in Casciotta and Arratia (1993)], and he augmented the existing datasets with many new characters and included most South American genera. Kullander (1998) did not include Central American and Greater Antillean heroins in his analysis; this was justified on the view that Central American cichlids essentially represent a single lineage within Heroini (see also Chakrabarty, 2006b). More recent phylogenetic work (Chakrabarty, 2006a; Concheiro-Perez et al., 2007; present study) has continued to support this idea, with the caveat that several taxa (e.g. Heroina, Caquetaia) represent South American exemplars of this largely Middle American heroin lineage (Kullander, 1998).

In agreement with other molecular or combined morphological and molecular studies (Farias et al., 1999, 2000, 2001; Sparks, 2004; Sparks and Smith, 2004), we have recovered the Neotropical cichlids as monophyletic. This is in contrast to Kullander (1998) whose optimal trees included both Ptychochrominae and Heterochromis in the least inclusive clade that included all cichlines (Fig. 1). Our relationships within Cichlinae differ from those of all previous phylogenetic studies. In contrast to previous studies that have typically reported strong re-sampling support $(>70 \%)$ for approximately one-quarter of the suprageneric cichline nodes, our results recovered strong support for approximately $80 \%$ of the suprageneric nodes.

\section{Retroculini, Cichlini, and Astronotini}

We recovered the genera Astronotus, Cichla, and Retroculus outside of the larger Chaetobranchini + Cichlasomatini + Geophagini + Heroini clade The separation of these genera from the remainder of the cichlines was also found in the nuclear gene and combined analyses of Farias et al. (2000), whereas all other multi-gene and combined analyses failed to separate these three genera from the remainder of the cichlines. Kullander's (1998) successive weighting 
analysis, but not his most parsimonious trees, recovered Retroculus sister to a clade composed of Heterochromis and the non-Retroculus cichlines (Fig. 1). This placement was unorthodox because previous studies (Regan, 1906; Cichocki, 1976) had consistently treated Retroculus as a geophagin. Kullander's unexpected placement of Retroculus as the sister group of all other cichlines was supported in essentially all subsequent molecular and combined family-level analyses. However, this study recovered a clade comprised of Cichla and Retroculus sister to the remainder of the cichlines (as did LópezFernández et al., 2005a). Kullander's Cichlinae (sensu stricto) also included Crenicichla, but the present study, like all molecular (Farias et al., 1999; Sparks, 2004; Sparks and Smith, 2004) and combined (Farias et al., 2000, 2001) analyses, recovered Crenicichla and Teleocichla within Geophagini (Figs 1 and 2).

Our analyses recovered Astronotus sister to all other cichlines (less Cichla and Retroculus). This placement separates Astronotus from Chaetobranchini (namely Chaetobranchus and Chaetobranchopsis) with which it has historically been allied on the basis of morphological evidence (Regan, 1906; Cichocki, 1976; Stiassny, 1991; Casciotta and Arratia, 1993; Kullander, 1998). However, molecular studies [except the $16 \mathrm{~S}$ analyses of Farias et al. (1999) and Sparks (2004)] and Kullander's (1998) optimal topology have separated Astronotus from Chaetobranchini.

Kullander (1998) treated Cichla and Retroculus as name-bearing types for cichlid subfamilies. In concordance with Sparks and Smith's (2004) biogeographically informative subfamilial taxonomy, we herein propose that Cichla and Retroculus be treated as the monogeneric cichline tribes Cichlini and Retroculini, respectively (see Appendix for subfamilial, tribal, and subtribal diagnoses and composition). Also, we propose that Astronotus be treated as the monogeneric cichline tribe Astronotini (see Appendix).

\section{Chaetobranchini}

As in all previous multi-gene or combined analyses that included chaetobranchins and geophagins (Farias et al., 2000, 2001; Sparks and Smith, 2004), we recovered Chaetobranchini as monophyletic and sister to Geophagini. Similarly, Kullander's (1998) equally weighted analysis recovered Chaetobranchus sister to his included geophagins (minus Crenicichla), a placement opposed to the hypothesis recovered in previous studies (Stiassny, 1991; Casciotta and Arratia, 1993) that recovered Chaetobranchini sister to Astronotus on the basis of several features, most notably similar microbranchiospine morphology. Herein, we propose that Chaetobranchopsis and Chaetobranchus be formally treated as the cichline tribe Chaetobranchini (Appendix).

\section{Geophagini (including $\uparrow$ Proterocara)}

Kullander (1998), Farias et al. (1999, 2000, 2001), and Sparks and Smith (2004) all examined geophagin relationships, but López-Fernández et al. (2005a,b) provided the most comprehensive phylogeny of geophagin cichlids to date. In addition to the taxa included in "Geophaginae" (our Geophagini) by Kullander (1998), molecular and combined analyses have recovered Teleocichla and Crenicichla within this assemblage (Farias et al., 1999, 2000; Sparks, 2004; Sparks and Smith, 2004; present study), in contrast to their placement with Cichla in previous morphological studies (Stiassny, 1987, 1991; Kullander, 1998). Furthermore, we herein recovered †Proterocara deeply nested within Geophagini; this is in contrast to its placement in Malabarba et al. (2006), which suggested that this extinct taxon belongs outside the Chaetobranchini + Cichlasomatini + Geophagini + Heroini clade.

Although our phylogeny shares many similarities with previous hypotheses, there are also many differences, particularly at higher levels within Geophagini. As for cichline relationships generally, this study was the first to recover strong re-sampling support for the majority of suprageneric geophagin clades. Despite various differences between the included and previous phylogenies, there are a number of geophagin clades that are consistently recovered across the diversity of published phylogenies. These include the sister-group pairing of Crenicichla and Teleocichla (Farias et al., 1999, 2000; Sparks, 2004; Sparks and Smith, 2004), the pairing of Acarichthys and Guianacara [Kullander, 1998; Farias et al., 1999, 2000; López-Fernández et al., 2005a,b (RAG2 only)], the pairing of Crenicara and Dicrossus (Kullander, 1998; López-Fernández et al., 2005a,b), and the pairing of Biotodoma and Gymnogeophagus (Farias et al., 2000, 2001).

Kullander (1998) recognized three tribes within his "Geophaginae". The monophyly of two of these tribes (our Crenicaratina and Geophagina) was not supported in the analyses of López-Fernández et al. (2005a,b). However, the current study largely recovered Kullander's (1998) tribal structure, particularly for the genera analysed by Kullander (1998). The limited changes to Kullander's tribal composition include the incorporation of Crenicichla, †Proterocara, and Teleocichla into the Crenicaratina and the movement of Mazarunia from the Crenicaratina to the Geophagina. Of these four genera, only Crenicichla was explicitly analysed in Kullander (1998). Herein, the three geophagin clades, first identified and treated as tribes by Kullander (1998), are recognized as the subtribes Acarichthyina, Crenicaratina, and Geophagina (Appendix). Despite essentially recovering the same geophagin clades as Kullander (1998), the current study's subtribal interrelationships differed in that Acarichthyina was recovered as the 
sister-group of Geophagina + Crenicaratina, albeit with limited support.

Acarichthyina is the least species-rich geophagin subtribe. Acarichthys is monotypic and Guianacara has five species (Kullander, 2003; López-Fernández et al., 2006). The monophyly of this subtribe has been corroborated in several molecular and combined studies (Farias et al., 1999, 2000; López-Fernández et al., 2005a,b), and there is ample evidence for the monophyly of Guianacara and its separation from its historical ally Aequidens (Kullander and Nijssen, 1989; Kullander, 1998; López-Fernández et al., 2006).

The composition of Crenicaratina, as recognized in the present study, differs from Kullander (1998) in that it includes Crenicichla, Teleocichla, and †Proterocara and it excludes Mazarunia. Crenicara and Dicrossus are well diagnosed and each has two species (Kullander and Staeck, 1990). Molecular and morphological data have consistently supported a close relationship between Crenicara and Dicrossus (López-Fernández et al., 2005a, b; present study). Similarly, molecular data have supported a close relationship between Teleocichla and Crenicichla, but the placement of these genera within Geophagini has varied among studies (Farias et al., 1999, 2000, 2001; Sparks and Smith, 2004; present study). Kullander (1998) intimated a close relationship between Crenicichla and Teleocichla and suggested that it was likely that Teleocichla was nested within Crenicichla, so additional phylogenetic research on the species-rich genus Crenicichla is required to address the taxonomy of these genera despite the clear support for their monophyly. Finally, there is the placement of the two species in the well-diagnosed genus Biotoecus (Kullander, 1989). Following Kullander's (1998) placement of Biotoecus with Crenicara and Dicrossus, only López-Fernández et al. (2005a,b) had tested this hypothesis. The analysis of morphological data in López-Fernández et al. (2005a) supported a close relationship between Biotoecus and Crenicara + Dicrossus, but their molecular and combined analyses (Farias et al., 2000; López-Fernández et al., 2005a,b) have generally suggested a close relationship between Biotoecus and Crenicichla. Finally, the current study and Malabarba et al. (2006) have suggested a close relationship between $\dagger$ Proterocara and Crenicichla. Our more apical placement of the Eocene $\dagger$ Proterocara within Cichlinae lends support to the idea that cichlids are of Cretaceous age and are considerably older than previously suggested (see also Sparks and Smith, 2004, 2005).

Geophagina is the largest of the geophagin subtribes with nine genera and approximately 121 species. Prior to the current study, none of the published molecular or combined studies has recovered a Geophagina with a composition approximating that of Kullander (1998; his Geophaginae). Additionally, the genus Geophagus, which has been consistently recovered as para- or polyphyletic when G. brasiliensis and G. steindachneri have been included (Kullander, 1998; Farias et al., 2001; López-Fernández et al., 2005a,b) was recovered as monophyletic and sister to Biotodoma + Gymnogeophagus in the present study. This assemblage was also recovered in Farias et al. (2000, 2001), but refuted in López-Fernández et al. (2005a,b) who frequently recovered Crenicara, Dicrossus, and/or Mikrogeophagus within this clade. The evidence for the monophyly and diagnoses of Gymnogeophagus and Biotodoma were discussed by Gosse (1976), Reis and Malabarba (1988), and Reis et al. (1992). In the current study, this Biotodoma + Geophagus + Gymnogeophagus clade was recovered as the sister group of a clade composed of Satanoperca and the "dwarf cichlids" (Apistogramma, Apistogrammoides, Mazarunia, Mikrogeophagus, and Taeniacara). Although there is evidence for the monophyly of the "dwarf cichlids" as a whole, Kullander (1998) suggested that Taeniacara and Apistogrammoides might be nested within the species-rich genus Apistogramma, and he separated Mazarunia and Mikrogeophagus from the other "dwarf cichlid" genera. Clearly, significant phylogenetic and revisionary work is needed within the "dwarf cichlids" to clarify generic limits. The sister-group pairing of Satanoperca and the "dwarf cichlids" has generally been recovered in molecular and combined studies (Farias et al., 1999, 2000, 2001; López-Fernández et al., 2005a,b), except that Mikrogeophagus has been typically separated from the other "dwarf cichlids". López-Fernández et al. (2005b) formally referred to this assemblage (minus Mazarunia and Mikrogeophagus) as the "Satanoperca clade". Our placement of Mazarunia in Geophagina contradicts the findings of Kullander (1990) who suggested that Mazarunia, Crenicara, and Dicrossus formed a clade. Kullander (1990) noted character conflict with his hypothesized relationships and highlighted that Mazarunia, Apistogramma, Taeniacara, Biotoecus, Hemichromis, Anomalochromis, and Dicrossus had lost their anguloarticular canal, but that it was present in Crenicara and other South American cichlids.

\section{Cichlasomatini}

Following Kullander's (1998) formal recognition of Cichlasomatini, all studies, except Sparks (2004), that have examined the relevant genera have recovered this clade (with the inclusion of Acaronia). Although the relationships recovered in the current study differ from Kullander (1998), Marescalchi (2005), and Musilová et al. (2008), there are many similarities including the separation of Aequidens (sensu stricto) from "Aequidens" hoehnei, "A." pulcher, and "A." rivulatus and the sistergroup relationship between Cleithracara and Nannacara (including Ivanacara). Similarly, the relationships are 
not identical to other molecular or combined analyses (Farias et al., 1999, 2000, 2001; Musilová et al., 2008), but there are more similarities than differences in the recovered relationships. The most comprehensive study of Cichlasomatini to date is Musilová et al. (2008) whose relationships were quite similar to ours. The only major difference is our placement of Laetacara sister to the Cleithracara-Nannacara clade (NIC clade of Musilová et al., 2008). Furthermore, the current study, like previous molecular and combined studies, found comparatively high support for subclades within Cichlasomatini. Herein, we follow Kullander (1998) in recognizing this clade (now including Acaronia) as the cichline tribe Cichlasomatini (Appendix).

Cichlasomatini (less Acaronia) was separated by Kullander (1983, 1986) and Stiassny (1991) from all other South American cichlids, and it is frequently referred to as the "cichlasomine group b" radiation. Historically, members of this tribe were classified in Aequidens, Cichlasoma, and Nannacara. The genera Nannacara and Cichlasoma (following its tremendous restriction in Kullander, 1983) have evidence for their monophyly (Kullander, 1983, 1988; Kullander and Prada-Pedreros, 1993; but see Musilová et al., 2008). Aequidens, however, has consistently been recovered as polyphyletic (Kullander, 1998; Farias et al., 2000; Marescalchi, 2005; Musilová et al., 2008; present study), so additional taxonomic work is clearly warranted. The remainder of the genera (Bujurquina, Cleithracara, Krobia, Laetacara, and Tahuantinsuyoa) were recently described and diagnosed by Kullander (1986) and Kullander and Nijssen (1989) as part of the ongoing refinement of the generic limits within this tribe. Ivanacara was recently described (Römer and Hahn, 2007) for Nannacara adoketa and N. bimaculata, but phylogenetic evidence supporting the reciprocal monophyly of Nannacara and Ivanacara remains to be demonstrated. The only phylogenetic studies to include both putative genera (Kullander, 1998; Musilová et al., 2008; present study) recovered the included species as a clade; thus, the evidence necessary to support their separation into two distinct genera is lacking.

\section{Heroini}

Among Neotropical cichlid tribes, no group has been explicitly examined as often as the Heroini; however, much of this phylogenetic work has focused on the less species-rich Middle American (vs. South American) component of this assemblage using only the mitochondrial Cyt- $b$ gene (Lydeard and Roe, 1997; Roe et al., 1997; Martin and Bermingham, 1998; Farias et al., 2001; Hulsey et al., 2006; Ríčan and Kullander, 2006; Concheiro-Perez et al., 2007). Heroins have also been examined using morphological data (Kullander, 1998;
Chakrabarty, 2007), partial mitochondrial sequences of the large ribosomal subunit (Farias et al., 1999; Sparks, 2004), multiple mitochondrial and nuclear gene sequences (Sparks and Smith, 2004; Chakrabarty, 2006a), and combined morphological and multi-gene molecular datasets (Farias et al., 2000, 2001; Chakrabarty, 2006b). Herein, we follow Kullander (1998) in recognizing this clade as the cichline tribe Heroini (Appendix).

With respect to prior studies (Kullander, 1983; Chakrabarty, 2006a,b; Ŕičan and Kullander, 2006; Concheiro-Perez et al., 2007), our phylogeny is in general agreement with results suggesting that the South American taxa Australoheros, Caquetaia, "Cichlasoma" festae, and Heroina are nested within a "Middle American" clade. Concheiro-Perez et al. (2007) and Hulsey et al. (2006) recovered the Greater Antillean genus Nandopsis as the sister group to all other members of the "Middle American" clade. Within the "Middle American" clade, our results are largely in agreement with Concheiro-Perez et al. (2007) who generally broke this assemblage into the informal "herichthyines" and "amphilophines", except that we recovered Australoheros and Theraps within the "amphilophines". Our placement of Australoheros is supported by the results of Rićcan and Kullander (2006), and although our placement of Theraps is unorthodox, this is more a reflection of the poor state of heroin taxonomy than a major phylogenetic change. Concheiro-Perez et al. (2007) recovered our included species, Theraps wesseli, among their "amphilophines", but they found the type species, T. irregularis, in its more traditional placement within their "herichthyines". Clearly, the demonstrable polyphyly of the Middle American genera Amphilophus, Archocentrus, "Cichlasoma", Theraps, Tomocichla, and Vieja [as recognized by Kullander (2003) and tested by Chakrabarty (2006a,b), Řiccan and Kullander (2006), and Concheiro-Perez et al. (2007)] renders our phylogeny within the "Middle American" clade largely preliminary. The combination of dense sampling of the "Middle American" heroins, as was analysed by Concheiro-Perez et al. (2007) using only Cyt- $b$ sequences, for multiple genes and morphology, as well as traditional revisionary work, will be required to resolve the complicated phylogeny and taxonomy of this species-rich assemblage.

As in prior studies, we recovered a "deep-bodied" clade sister to the "Middle American" clade. Previous phylogenies have generally recovered a "deep-bodied" clade composed of Heros, Mesonauta, Symphysodon, and Uaru (Farias et al., 2000, 2001; Concheiro-Perez et al., 2007), but the placement of Pterophyllum has been more elusive. In previous studies, the placement of Pterophyllum has ranged from within this "deepbodied" clade (Farias et al., 2000), to the sister-group of all other heroins (Farias et al., 1999, 2001), to the 
sister-group of a combined Cichlasomatini + Heroini (Concheiro-Perez et al., 2007). We recovered Pterophyllum in a more traditional placement (Regan, 1906), sister to Symphysodon, within the "deep-bodied" clade. Finally, our analysis recovered a clade composed of Hoplarchus + Hypselecara that was sister to all other heroins. Typically, these genera have fallen out near each other (often sister), but their placement has also varied from a close relationship with Symphysodon (Farias et al., 1999) to their current placement as the sister-group of all other heroins (Farias et al., 2000).

The taxonomy of Heroini, or what has often been referred to as the "cichlasomine group a" radiation (Stiassny, 1991), is complicated, but most of this controversy revolves around the limits of the former Cichlasoma and the Middle American species. As noted above, the demonstrable polyphyly of the Middle American genera Amphilophus, Archocentrus, "Cichlasoma", Theraps, Tomocichla, and Vieja makes any discussion of Middle American taxonomy futile in the absence of a species-level analysis. Among the South American heroins, monophyly of the genera within the "deep-bodied" clade (Heros, Mesonauta, Pterophyllum, Symphysodon, and Uaru) has been previously discussed (Kullander, 1986; Kullander and Silfvergrip, 1991; Bleher et al., 2007) or are indisputable because of their extreme modifications (e.g. the popular aquarium angelfishes in Pterophyllum). Monophyly of the other South American heroin genera was discussed in their descriptions [Kullander, 1986 (Hypselecara); Kullander, 1998 (Heroina); Ŕíčan and Kullander, 2006 (Australoheros)] and in subsequent phylogenetic revisions (SchmitterSoto, 2007). Finally, monophyly of the small genus Caquetaia and the monotypic genus Hoplarchus has not been explicitly discussed, but Říčan and Kullander (2006) did recover Heroina nested within Caquetaia.

\section{Evolution of Cichlinae}

In the first family-level molecular phylogeny for Cichlidae, Farias et al. (1999) noted that Neotropical cichlines harbour significantly higher levels of genetic variation than their African pseudocrenilabrine sister group. They argued that cichlines had experienced accelerated rates of molecular evolution, and they highlighted their finding that a particularly high evolutionary rate was found within Geophagini. In agreement with Farias et al. (2000, 2001), the present study found support for these comparatively longer geophagin branches. Despite the significantly longer branches found within Geophagini (Farias et al., 1999), LópezFernández et al. (2005b) suggested that geophagins represented an adaptive radiation that was characterized, in part, by "short basal branches". López-Fernández et al. (2005b, p. 242) argued that it was "improbable that (their) lack of resolution and support at the base of the geophagine tree is due to either inadequate or insufficient data. Instead short branches at the base of the tree suggest that the different geophagine genera may have originated rapidly and/or over a short period" of time. Short basal branches are used by these authors as evidence to satisfy Schluter's (2000) phylogenetic requirements for an adaptive radiation.

In contrast to the findings of López-Fernández et al. (2005a,b), the current study, which included additional geophagin genera, outgroups, and data, does not reveal "short basal branches" with limited support (Fig. 2). In contrast to all previous studies, we recovered strong support and ample branch lengths for the majority of the suprageneric nodes within Geophagini. These findings minimally question, if not outright reject, the phylogenetic evidence for geophagins representing a rapid radiation.

In this study, we have included complete generic sampling of Neotropical cichlids and have incorporated substantial novel genetic data in a simultaneous analysis of available morphological and molecular data. This significant increase in data has resulted in the first well-supported tribal, sub-tribal, and generic phylogeny for Cichlinae, and we have updated Kullander's (1998, 2003) taxonomy accordingly. Despite this phylogenetic progress, many taxonomic problems remain, including the limits of many of the species-rich genera (e.g. Apistogramma, Aequidens, Crenicichla) and the classification of the "Middle American" heroins. Clearly, detailed species-level phylogenies and type-based revisionary studies for most of these problematic clades are the next step in further resolving cichline relationships.

\section{Acknowledgements}

We thank P. Loiselle, R. Schelly, and M. Stiassny for many fruitful discussions related to cichlids and the results of this project. Additionally, we thank J. Faivovich, T. Grant, S. Schaefer, and K. Smith for thoughtful discussions and/or reading complete or partial drafts of this manuscript. We thank W. Wheeler for kindly providing laboratory space and equipment. We thank L. Demason, P. Esselman, J. Friel, H. López-Fernández, P. Loiselle, O. Lucanus, R. Oldfield, J. Rapps, P. Reinthal, K. Riseng, C. Rodríguez, M. Sabaj, J. Schmitter-Soto, A. Simons, M. Stiassny, and H. Walker for providing, helping locate, or helping in the collection of tissue samples. Finally, fieldwork and laboratory research was funded by the AMNH, AMNH Lerner-Gray Fund, Carl and Laura Hubbs Endowment, and the National Science Foundation (grants: DEB-0405246, DEB-0444842, and DEB-0716155). 


\section{References}

Barlow, G.W., 2000. The Cichlid Fishes: Nature's Grand Experiment in Evolution. Perseus Publishing, Cambridge, MA.

Bernardi, G., Bucciarelli, G., 1999. Molecular phylogeny and speciation of the surfperches (Embiotocidae: Perciformes). Mol. Phylogenet. Evol. 13, 77-81.

Bleher, H., Stölting, K.N., Salzburger, W., Meyer, A., 2007. Revision of the genus Symphysodon Heckel, 1840 (Teleostei: Perciformes: Cichlidae) based on molecular and morphological characters. Aqua $12,133-174$.

Bremer, K., 1994. Branch support and tree stability. Cladistics 10, 295 304.

Casciotta, J., Arratia, G., 1993. Tertiary cichlid fishes from Argentina and reassessment of the phylogeny of new world cichlids. Kaupia 2, 195-250.

Chakrabarty, P., 2004. Cichlid biogeography: comment and review. Fish Fish. 5, 97-119.

Chakrabarty, P., 2006a. Systematics and historical biogeography of Greater Antillean Cichlidae. Mol. Phylogenet. Evol. 39, 619-627.

Chakrabarty, P., 2006b. Phylogenetic and biogeographic analyses of Greater Antillean and Middle American Cichlidae. Unpublished $\mathrm{PhD}$ Thesis, University of Michigan, Ann Arbor.

Chakrabarty, P., 2007. A morphological phylogenetic analysis of Middle American cichlids with special emphasis on the section 'Nandopsis' sensu Regan. Misc. Publ. Mus Zool. Univ. Michigan. 198, 1-31.

Chakrabarty, P., Sparks, J.S., 2007. Relationships of the New World cichlid genus Hypsophrys Agassiz 1859 (Teleostei: Cichlidae), with diagnoses for the genus and its species. Zootaxa 1523, 59-64.

Cichocki, F.P. 1976. Cladistic history of cichlid fishes and reproductive strategies of the American genera Acarichthys, Biotodoma, and Geophagus. Unpublished PhD Thesis, University of Michigan, Ann Arbor.

Concheiro-Perez, G.A., Říčan, O., Ortí, G., Bermingham, E., Doadrio, I., Zardoya, R., 2007. Phylogeny and biogeography of 91 species of heroine cichlids (Teleostei: Cichlidae) based on sequences of the Cytochrome $b$ gene. Mol. Phylogenet. Evol. 43, 91-110.

Farias, I.P., Ortí, G., Sampaio, I., Schneider, H., Meyer, A., 1999. Mitochondrial DNA phylogeny of the family Cichlidae: monophyly and fast molecular evolution of the Neotropical assemblage. J. Mol. Evol. 48, 703-711.

Farias, I.P., Ortí, G., Meyer, A., 2000. Total evidence: molecules, morphology, and the phylogenetics of cichlid fishes. J. Exp. Zool. 288, 76-92.

Farias, I.P., Ortí, G., Sampaio, I., Schneider, H., Meyer, A., 2001. The Cytochrome $b$ gene as a phylogenetic marker: the limits of resolution for analyzing relationships among cichlid fishes. J. Mol. Evol. 53, 89-103.

Farris, J.S., 1989. The retention index and the rescaled consistency index. Cladistics 5, 417-419.

Goloboff, P.A., 1999. Analyzing large data sets in reasonable times: solutions for composite optima. Cladistics 15, 415-428.

Gosse, J.P., 1971. Révision du genre Retroculus (Castelnau, 1855), designation d'un neotype de Retroculus lapidifer (Castelnau, 1855) et description de deux espèces nouvelles. Bull. Inst. R. Sci. Nat. Belgique 47, 1-13.

Gosse, J.P., 1976. Révision du genre Geophagus (Pisces Cichlidae). Mem. Acad. Roy. Sci. d'Outre-Mer (Bruxelles) 19, 1-173.

Hall, T.A., 1999. BioEdit: a user-friendly biological sequence alignment editor and analysis program for Windows 95/98/NT. Nucleic Acids Symp. Ser. 41, 95-98.

Higham, T.E., Hulsey, C.D., Říčan, O., Carroll, A.M., 2007. Feeding with speed: prey capture evolution in cichilds. J. Evol. Biol. 20, 70-78.

Hulsey, C.D., García De León, F.J., Rodiles-Hernández, R., 2006. Micro- and macroevolutionary decoupling of cichlid jaws: a test of Liem's key innovation hypothesis. Evolution 60, 2096-2109.
Keenleyside, M. (Ed.), 1991. Cichlid Fishes: Behavior, Ecology and Evolution. Chapman and Hall, London.

Kluge, A.G., Farris, J.S., 1969. Quantitative phyletics and the evolution of anurans. Syst. Zool. 18, 1-32.

Kornfield, I., Smith, P.F., 2000. African cichlid fishes: model systems for evolutionary biology. Ann. Rev. Ecol. Syst. 31, 163-196.

Kullander, S.O., 1983. A Revision of the South American Cichlid Genus Cichlasoma (Teleostei: Cichlidae). Natruhistoriska Riksmuseet, Stockholm.

Kullander, S.O., 1986. Cichlid Fishes of the Amazon River Drainage of Peru. Swedish Museum of Natural History, Stockholm.

Kullander, S.O., 1988. Teleocichla, a new genus of South American rheophilic cichlid fishes with six new species (Teleostei: Cichlidae). Copeia 1988, 196-230.

Kullander, S.O., 1989. Biotoecus Eigenmann and Kennedy (Teleostei: Cichlidae): description of a new species from the Orinoco Basin and revised generic diagnosis. J. Nat. Hist. 23, 225-260.

Kullander, S.O., 1990. Mazarunia mazarunii (Teleostei: Cichlidae), a new genus and species from Guyana, South America. Ichthyol. Explor. Freshw. 1, 3-14.

Kullander, S.O. 1998. A phylogeny and classification of the South American Cichlidae (Teleostei: Perciformes). In: Malabarba, L.R., Reis, R.E., Vari, R.P., Lucena, Z.M., Lucena, C.A.S. (Eds.), Phylogeny and Classification of Neotropical Fishes. EDIPUCRS, Porto Alegre, Brazil, pp. 461-498.

Kullander, S.O. 2003. Family Cichlidae. In: Reis, R.E., Kullander, S.O., Ferraris, C.J. Jr (Eds.), Checklist of the Freshwater Fishes of South and Central America. EDIPUCRS, Porto Alegre, Brazil, pp. 605-654.

Kullander, S.O., Ferreira, E.J.G., 2006. A review of the South American cichlid genus Cichla with descriptions of nine new species (Teleostei: Cichlidae). Ichthyol. Explor. Freshw. 17, 289-398.

Kullander, S.O., Nijssen, H.. 1989. The Cichlids of Surinam. Teleostei: Labroidei. E. J. Brill, Leiden.

Kullander, S.O., Prada-Pedreros, S., 1993. Nannacara adoketa, a new species of cichlid fish from the Rio Negro in Brazil. Ichthyol. Explor. Freshw. 4, 357-366.

Kullander, S.O., Silfvergrip, A.M.C., 1991. Review of the South American cichlid genus Mesonauta Günther (Teleostei, Cichlidae) with descriptions of two new species. Rev. Suisse Zool. 98, 407-448.

Kullander, S.O., Staeck, W., 1990. Crenicara latruncularium (Teleostei, Cichlidae), a new cichlid species from Brazil and Bolivia. Cybium $14,161-173$.

Kumazawa, Y., Yamaguchi, M., Nishida, M. 1999. Mitochondrial molecular clocks and the origin of euteleostean biodiversity: familial radiation of perciforms may have predated the Cretaceous/Tertiary boundary. In: Kato, M. (Ed.), The Biology of Biodiversity. Springer-Verlag, Tokyo, pp. 35-52.

López-Fernández, H., Honeycutt, R.L., Stiassny, M.L.J., Winemiller, K.O., 2005a. Morphology, molecules, and character congruence in the phylogeny of South American geophagine cichlids (Perciformes, Labroidei). Zool. Scr. 34, 627-651.

López-Fernández, H., Honeycutt, R.L., Winemiller, K.O., 2005b. Molecular phylogeny and evidence for an adaptive radiation of geophagine cichlids from South America (Perciformes: Labroidei). Mol. Phylogenet. Evol. 34, 227-244.

López-Fernández, H., Baechle, D.C.T., Kullander, S.O., 2006. Two new species of Guianacara from the Guiana Shield of eastern Venezuela (Perciformes: Cichlidae). Copeia 2006, 384-395.

Lydeard, C., Roe, K.J. 1997. The phylogenetic utility of the mitochondrial Cytochrome $b$ gene for inferring relationships of actinopterygian fishes. In: Stepien, C., Kocher, T. (Eds.), Molecular Systematics of Fishes. Academic Press, San Diego, pp. 285 303.

Malabarba, M.C., Zuleta, O., Del Papa, C., 2006. Proterocara argentina, a new fossil cichlid from the Lumbrera Formation, Eocene of Argentina. J. Vertebr. Paleontol. 26, 267-275. 
Marescalchi, O., 2005. Karyotype and mitochondrial 16S gene characterizations in seven South American Cichlasomatini species (Perciformes, Cichlidae). J. Zool. Syst. Evol. Res. 43, 22-28.

Martin, A.P., Bermingham, E., 1998. Systematics and evolution of lower Central American cichlids inferred from analysis of Cytochrome $b$ gene sequences. Mol. Phylogenet. Evol. 9, 192-203.

Mayer, W.E., Tichy, H., Klein, J., 1998. Phylogeny of African cichlid fishes as revealed by molecular makers. Heredity 80, 702-714.

Musilová, Z., Řičcan, O., Janko, K., Novák, J., 2008. Molecular phylogeny and biogeography of the Neotropical cichlid fish tribe Cichlasomatini (Teleostei: Cichlidae: Cichlasomatinae). Mol. Phylogenet. Evol. 46, 659-672.

Nelson, J.S., 2006. Fishes of the World, 4th edn. John Wiley and Sons, New York.

Nixon, K.C., 1999. The parsimony ratchet, a new method for rapid parsimony analysis. Cladistics 15, 407-414.

Nixon, K.C., 2002. WinClada, vers. 1.00.8. Published by the author, Ithaca, NY.

Norell, M.A., Wheeler, W.C., 2003. Missing entry replacement data analysis: a statistical approach to dealing with missing data in paleontological and total evidence data sets. J. Vertebr. Paleontol. 23, 275-283.

Oliver, M.K. 1984. Systematics of African cichlid fishes: determination of the most primitive taxon, and studies on the haplochromines of Lake Malawi (Teleostei: Cichlidae). Unpublished PhD Thesis, Yale University, New Haven, CT.

Regan, C.T., 1906. A revision of the fishes of the South-American cichlid genera of Cichla, Chaetobranchus, and Chaetobranchopsis, with notes on the genera of American Cichlidae. Ann. Mag. Nat. Hist. 7, 230-239.

Reis, R.E., Malabarba, L.R., 1988. Revision of the Neotropical cichlid genus Gymnogeophagus Ribeiro, 1918, with descriptions of two new species (Pisces, Perciformes). Rev. Bras. Zool. 4, 259-305.

Reis, R.E., Malabarba, L.R., Pavanelli, C.S., 1992. Gymnogeophagus setequedas, a new cichlid species (Teleostei: Labroidei) from middle rio Paraná system, Brazil and Paraguay. Ichthyol. Explor. Freshw. 3, 265-272.

Říčan, O., Kullander, S.O., 2006. Character- and tree-based delimitation of species in the 'Cichlasoma' facetum group (Teleostei, Cichlidae) with the description of a new genus. J. Zool. Syst. Evol. Res. 44, 136-152.

Roe, K.J., Conkel, D., Lydeard, C., 1997. Molecular systematics of Middle American cichlid fishes and the evolution of trophic-types in 'Cichlasoma (Amphilophus)' and 'C. (Thorichthys)'. Mol. Phylogenet. Evol. 7, 366-376.

Römer, U., Hahn, I., 2007. Ivanacara gen n. (Teleostei: Perciformes, Cichlasomatini - a new genus of cichlids from the Neotropics. Cichlid Atlas 2, 1190-1197.

Salzburger, W., Baric, S., Sturmbauer, C., 2002a. Speciation via introgressive hybridization in east African cichlids? Mol. Ecol. 11, 619-625.

Salzburger, W., Meyer, A., Baric, S., Verheyen, E., Sturmbauer, C., 2002b. Phylogeny of the Lake Tanganyika cichlid species flock and its relationship to the central and east African haplochromine cichlid fish faunas. Syst. Biol. 51, 113-135.

Schelly, R.C., Salzburger, W., Koblmuller, S., Duftner, N., Sturmbauer, C., 2006. Phylogenetic relationships of the lamprologine cichlid genus Lepidiolamprologus (Teleostei: Perciformes) based on mitochondrial and nuclear sequences, suggesting introgressive hybridization. Mol. Phylogenet. Evol. 38, 426-438.

Schliewen, U., Klee, B., 2004. Reticulate sympatric speciation in Cameroonian crater lake cichlids. Front. Zool. 1, 1-5.

Schluter, D., 2000. The Ecology of Adaptive Radiation. Oxford University Press, Oxford.

Schmitter-Soto, J.J., 2007. Phylogeny of species formerly assigned to the genus Archocentrus (Perciformes: Cichlidae). Zootaxa 1618, $1-50$.
Seegers, L., Sonnenberg, R., Yamamoto, R., 1999. Molecular analysis of the Alcolapia flock from lakes Natron and Magadi Tanzani and Kenya (Teleostei: Cichlinae), and implications for the systematics and evolution. Ichthyol. Explor. Freshw. 10, 175-199.

Smith, W.L., Craig, M.T., 2007. Casting the percomorph net widely: the importance of broad taxonomic sampling in the search for the placement of serranid and percid fishes. Copeia 2007, 35-55.

Smith, W.L., Wheeler, W.C., 2004. Polyphyly of the mail-cheeked fishes (Teleostei: Scorpaeniformes): evidence from mitochondrial and nuclear sequence data. Mol. Phylogenet. Evol. 32, 627-646.

Smith, W.L., Wheeler, W.C., 2006. Venom evolution widespread in fishes: a phylogenetic road map for the bioprospecting of piscine venoms. J. Hered. 97, 206-217.

Song, C.B., Near, T.J., Page, L.M., 1998. Phylogenetic relations among percid fishes as inferred from mitochondrial Cytochrome $b$ DNA sequence data. Mol. Phylogenet. Evol. 10, 343-353.

Sorenson, M.D., 1999. TreeRot, vers. 2c. Published by the author, Boston University, Boston, MA.

Sparks, J.S., 2004. Molecular phylogeny and biogeography of the Malagasy and south Asian cichlids (Teleostei: Perciformes: Cichlidae). Mol. Phylogenet. Evol. 30, 599-614.

Sparks, J.S., 2008. Phylogeny of the cichlid subfamily Etroplinae and taxonomic revision of the Malagasy cichlid genus Paretroplus (Teleostei: Cichlidae). Bull. Am. Mus. Nat. Hist. 314, 1-151.

Sparks, J.S., Smith, W.L., 2004. Phylogeny and biogeography of cichlid fishes (Teleostei: Perciformes: Cichlidae). Cladistics 20, 501517.

Sparks, J.S., Smith, W.L., 2005. Freshwater fishes, dispersal ability, and nonevidence: "Gondwana life rafts" to the rescue. Syst. Biol. $54,158-165$.

Sparks, J.S., Dunlap, P.V., Smith, W.L., 2005. Evolution and diversification of a sexually dimorphic luminescent system in ponyfishes (Teleostei: Leiognathidae), including diagnoses for two new genera. Cladistics 21, 305-327.

Stiassny, M.L.J., 1987. Cichlid familial intrarelationships and the placement of the Neotropical genus Cichla (Perciformes: Labroidei). J. Nat. Hist. 21, 1311-1331.

Stiassny, M.L.J.. 1991. Phylogenetic intrarelationships of the family Cichlidae: an overview. In: Keenleyside, M.H.A. (Ed.), Cichlid Fishes: Behaviour, Ecology, and Evolution. Chapman and Hall, London, pp. 1-35.

Stiassny, M.L.J., Sparks, J.S., 2006. Phylogeny and taxonomic revision of the endemic Malagasy genus Ptychochromis (Teleostei, Cichlidae), with the description of five new species and a diagnosis for Katria, new genus. Am. Mus. Novit. 3535, 1-55.

Streelman, J.T., Karl, S.A., 1997. Reconstructing labroid evolution with single-copy nuclear DNA. Proc. R. Soc. Lond. B, 264, 10111020.

Swofford, D.L., 2002. PAUP*: phylogenetic analysis using parsimony (*and other methods), vers. 4.0b10. Sinauer Associates, Sunderland, MA.

Westneat, M.W., Alfaro, M.E., 2005. Phylogenetic relationships and evolutionary history of the reef fish family Labridae. Mol. Phylogenet. Evol. 36, 370-390.

Wheeler, W.C., 1996. Optimization alignment: the end of multiple sequence alignment in phylogenetics. Cladistics 12, 1-9.

Wheeler, W.C., 2003a. Implied alignment: a synapomorphy-based multiple sequence alignment method. Cladistics 19, 261-268.

Wheeler, W.C., 2003b. Iterative pass optimization of sequence data. Cladistics 19, 254-260.

Wheeler, W.C., Gladstein, D., DeLaet, J., 2003. POY, vers. 3.0. Published by the American Museum of Natural History, NY.

Wheeler, W.C., Aagesen, L., Arango, C.P., Faivovich, J., Grant, T., D'haese, C., Janies, D., Smith, W.L., Varón, A., Giribet, G., 2006. Dynamic Homology and Phylogenetic Systematics: A Unified Approach Using POY. American Museum of Natural History, New York. 
Zardoya, R., Vollmer, D.M., Craddock, C., Streelman, J.T., Karl, S., Meyer, A., 1996. Evolutionary conservation of microsatellite flanking region and their use in resolving the phylogeny of cichlid fishes (Pisces: Perciformes). Proc. R. Soc. Lond. B Biol. Sci. 263, 1589-1598.

\section{Appendix}

Proposed classification, morphological diagnoses, and composition of Cichlinae and its included tribes and subtribes.

Cichlinae Bonaparte 1840

Type genus: Cichla Bloch and Schneider 1801.

Sister taxon: Pseudocrenilabrinae.

Concept and content: Approximately 480 species classified in seven tribes: Astronotini, Chaetobranchini, Cichlasomatini, Cichlini, Geophagini, Heroini, and Retroculini.

Diagnostic feature: Stiassny (1991) diagnosed Cichlinae with one morphological feature: strongly interdigitating suture between vomerine shaft and parasphenoid bar.

\section{Astronotini Hoedeman 1947}

Type genus: Astronotus Swainson 1839.

Sister taxon: Chaetobranchini + Cichlasomatini + Geophagini + Heroini.

Concept and content: Two species classified in the genus Astronotus (Kullander, 2003).

Diagnostic features: The current study recovered five morphological apomorphies that diagnose Astronotini: microbranchiospines enlarged, with numerous teeth on exposed face (Kullander, 1998: character 13); insertion of pharyngocleithralis internus onto lower jaw complex with several tendons (Kullander, 1998: character 24); narrow insertion of Baudelot's ligament onto bilateral minor process on basioccipital (Kullander, 1998: character 29); no caudal opening of posterior myodome (Kullander, 1998: character 30); 17-20 anal-fin elements (Kullander, 1998: character 81).

\section{Chaetobranchini Fernández-Yépez 1951}

Type genus: Chaetobranchus Heckel 1840.

Sister taxon: Geophagini.

Concept and content: Four species classified in two genera: Chaetobranchus and Chaetobranchopsis with two species each (Kullander, 2003).

Diagnostic feature: Casciotta and Arratia (1991) identified the following diagnostic morphological feature for Chaetobranchini: uncinate process of first epibranchial much longer than anterior arm.

\section{Cichlasomatini Kullander, 1998}

Type genus: Cichlasoma Swainson 1839.

Sister taxon: Heroini.

Concept and content: Approximately 107 species classified in ten genera: Acaronia, Aequidens, Bujurquina, Cichlasoma, Cleithracara, Krobia, Laetacara, Nannacara, and Tahuantinsuyoa (Kullander, 2003).

Diagnostic features: The current study recovered four morphological synapomorphies that diagnose Cichlasomatini: suturing of mesethmoid and vomer absent (Kullander, 1998: character 31); anterior two post-lachrymal infraorbitals variously ossified with laminar ventral expansion (Kullander, 1998: character 43); no posterior expansion of gas bladder into caudal region (Kullander, 1998: character 74); predorsal scales triserial (Kullander, 1998: character 80).

\section{Cichlini Bonaparte 1840}

Type genus: Cichla Bloch and Schneider 1801.

Sister taxon: Retroculini.

Concept and content: Approximately 15 species classified in the genus Cichla (Kullander and Ferreira, 2006).

Diagnostic features: The current study recovered 13 morphological apomorphies that diagnose Cichlini [see Kullander and Ferreira (2006) for additional characters and discussion]: uncinate process of epibranchial 1 wider than anterior arm (Kullander, 1998: character 4); epibranchial 1 with posterodorsal laminar expansion with sharp angle (Kullander, 1998: character 8); central ligament inserts on ceratobranchial 4 (Kullander, 1998: character 11); microbranchiospines with teeth on exposed face (Kullander, 1998: character 13); origin of pharyngocleithralis internus on the lateral face of cleithrum (Kullander, 1998: character 23); urohyal spine rostrally directed (Kullander, 1998: character 25); Baudelot's ligament with narrow insertion on bilateral minor process of basioccipital (Kullander, 1998: character 29); anterior notch on vomer (Kullander, 1998: character 32); anteriorly directed process on distal postcleithrum long and pointed (Kullander, 1998: character 49); anterodorsal palatomaxillary ligament well defined and originating from distinct dorsolateral fossa found approximately (at midpoint) on maxillary process of palatine (Kullander, 1998: character 53); ascending arm of premaxilla shorter than dentigerous arm (Kullander, 1998: character 64); abdominal vertebrae 13 or fewer (Kullander, 1998: character 67); final basapophysis on last abdominal vertebra (Kullander, 1998: character 68).

\section{Geophagini Haseman 1911}

Type genus: Geophagus Heckel 1840.

Sister taxon: Chaetobranchini.

Concept and content: Approximately 217 species (Kullander, 2003; López-Fernández et al., 2005a, 2006) classified into three subtribes: Acarichthyina, Crenicaratina, and Geophagina.

Diagnostic features: The current study recovered three morphological synapomorphies that diagnose Geophagini [see LópezFernández et al. (2005b) for additional characters and discussion]: uncinate process of epibranchial 1 wider than anterior process (Kullander, 1998: character 4); one supraneural (Kullander, 1998: character 66); more than three procurrent caudal-fin rays (Kullander, 1998: character 84).

\section{Acarichthyina Kullander, 1998}

Type genus: Acarichthys Eigenmann 1912.

Sister taxon: Crenicaratina + Geophagina.

Concept and content: Approximately seven species (Kullander, 2003; López-Fernández et al., 2006) classified in the genera Acarichthys and Guianacara.

Diagnostic features: The current study recovered four morphological synapomorphies that diagnose Acarichthyina: expanded basisphenoid and dorsal parasphenoid wing (Kullander, 1998: character 36); extensive overlap of lachrymal and first infraorbital (Kullander, 1998: character 44); anteroventral articulation of palatine slightly displaced from vomer, but maintaining ligamentous connection (Kullander, 1998: character 54); pelvic-fin shape pointed (Kullander, 1998: character 86).

Crenicaratina Kullander, 1998

Type genus: Crenicara Steindachner 1875 .

Sister taxon: Geophagina.

Concept and content: Approximately 89 species (Kullander, 2003) classified in six extant genera: Biotoecus, Crenicara, Crenicichla, Dicrossus, and Teleocichla. 
Diagnostic features: The current study recovered one morphological synapomorphy that diagnoses the Crenicaratina: caudal-fin lateral line absent (Kullander, 1998: character 78).

Geophagina Haseman 1911

Type genus: Geophagus Heckel 1840.

Sister taxon: Crenicaratina.

Concept and content: Approximately 121 species (Kullander, 2003) classified in nine genera: Apistogramma, Apistogrammoides, Biotodoma, Geophagus, Gymnogeophagus, Mazarunia, Mikrogeophagus, Satanoperca, and Taeniacara.

Diagnostic features: The current study recovered four morphological synapomorphies that diagnose Geophagina: uncinate process of epibranchial 1 relative to main axis of bone parallel or at very slight angle (Kullander, 1998: character 3); epibranchial lobe present (Kullander, 1998: character 5); interarcual cartilage long (Kullander, 1998: character 22); single palatoethmoid articulation (Kullander, 1998: character 59).

Heroini Kullander, 1998

Type genus: Heros Heckel 1840.

Sister taxon: Cichlasomatini.

Concept and content: Approximately 142 species classified in 26 genera (Kullander, 2003; Chakrabarty, 2006a; Řičan and Kullander, 2006; Chakrabarty and Sparks, 2007; Schmitter-Soto, 2007):
Amatitlania, Amphilophus, Archocentrus, Australoheros, Caquetaia, "Cichlasoma", Herichthys, Heroina, Heros, Herotilapia, Hoplarchus, Hypselecara, Hypsophrys, Mesonauta, Nandopsis, Parachromis, Paraneetroplus, Petenia, Pterophyllum, Rocio, Symphysodon, Theraps, Thorichthys, Tomocichla, Uaru, and Vieja.

Diagnostic features: The current study recovered three morphological synapomorphies that diagnose Heroini: palatine displaced, lacking contact with vomer (Kullander, 1998: character 54); single (posterior) palatoethmoid articulation (Kullander, 1998: character 59); five or more anal-fin spines (Kullander, 1998: character 82).

Retroculini Kullander, 1998

Type genus: Retroculus Eigenmann and Bray 1894.

Sister taxon: Cichlini.

Concept and content: Approximately three species classified in the genus Retroculus (Gosse, 1971; Kullander, 2003).

Diagnostic features: The current study recovered six morphological apomorphies that diagnose Retroculini: uncinate process of epibranchial 1 considerably longer than anterior arm (Kullander, 1998: character 1); both uncinate process and anterior arm of epibranchial 1 posterodorsally angled without deep indentation in dorsal bone margin (Kullander, 1998: character 3); gill rakers on ceratobranchial 5 (Kullander, 1998: character 18); articulating process of premaxilla indistinct (Kullander, 1998: character 63); dorsal caudal-fin lateral line absent (Kullander, 1998: character 78); "Tilapia spot" present (Kullander, 1998: character 91). 